\title{
Values of Local Wisdom in Traditional Games Penyu Mataluh in Serangan: Study Ethnopedagogy
}

\author{
I Wayan Rasna ${ }^{1 *}$, Ni Putu Pande Tresnayani ${ }^{2}$ iD \\ ${ }^{1,2}$ Universitas Pendidikan Ganesha, Singaraja, Indonesia \\ *Corresponding author: wayanrasna@ymail.com
}

\begin{abstract}
This study aims to examine the form and value of local wisdom contained in the traditional game of the penyu mataluh in Serangan from an ethnopedagogy point of view. The research data are in the form of descriptions of body movements in the steps of the game and song lyrics that show the value of local wisdom. Sources of data in this study are children who play the traditional game of the penyu mataluh and the community. The data collection method is the method of listening, taking notes, observing, and interviewing. The data analysis technique used is descriptive analysis including data reduction, data presentation, and drawing conclusions. The results showed that the penyu mataluh game has a form of local wisdom in the form of words, namely, poetry that is sung when playing and actions in the form of body movements that are reflected in the steps of the game. This game can be preserved by making game applications that can be downloaded on mobile phones similar to the original game, teaching the game in schools and cultural studios, and more research on local wisdom on traditional games.
\end{abstract}

Keywords: Values, Games, Traditional

\begin{tabular}{lll}
\hline History: & & Publisher: Undiksha Press \\
Received & : March 20, 2021 & Licensed: This work is licensed under \\
Revised & : March 22, 2021 & a Creative Commons Attribution 3.0 License \\
Accepted & : June 24, 2021 & Cablished \\
: July 25, 2021
\end{tabular}

\section{INTRODUCTION}

Technological developments in modern times have resulted in rapid progress in various fields, one of which is a variety of sophisticated games spread throughout the world Public. Games can push creative activity, imagination and social attitude. Through the games carried out, positive characters will be formed that are useful for life (Kurniasari \& Rahardi, 2019; Ratih, 2019). Advances in technology make it easy for children to enjoy games which can be downloaded in cell phone. This phenomenon is the reason why traditional games are abandoned and are rarely played by children (Anggita, 2019; Aqobah et al., 2020) conveying a lack of knowledge society about traditional games due to technological advances that focus on modern games. Another reason that causes the decline of traditional games in the community is the existence of internet facilities.

Based on a survey conducted by APJII (Association of Indonesian Internet Service Providers) in 2016 explained that of the 256,2 million Indonesian population 132,7 million are internet users where students and students occupy the top rank with $89,7 \%$ and $69,8 \%$ of workers 58,5\%, household workers 25,3 and others 6,7\% (Lacksana, 2017). From this survey, it can be seen that the use of the internet network is in great demand so that they are more interested in surfing the internet than doing traditional game activities. In addition, the playing field is getting smaller and even lost and progress in the field of TV shows is finally coming pamper children to sit quietly at home instead of going outside to play. Even though each region in Indonesia has various types of traditional games, one of which is in Bali, namely the game the traditional penyu mataluh. Traditional game a form of expression and appreciation of community traditions in creating fun and joyful situations and activities. Traditional games are games that are passed down from generation to generation which are spread by word of mouth and have various benefits that are felt by the players because they 
can build character and contain the value of local wisdom that must be preserved (Kartiningsih \& Budiaman, 2020; Susanti, 2016). This was also conveyed that traditional games contain the value of local wisdom that can train players to have thinking skills, be brave, be honest, love the environment, and nationalism (Kurniasari \& Rahardi, 2019). Based on the results of an interview with MT, who is one of the historians and maestro of traditional Balinese games, information was obtained that the game traditional penyu mataluh which is located in the province of Bali, was first discovered in the Serangan area, South Denpasar District, Denpasar City. This was also conveyed in the results of research in a documentary film on traditional games penyu mataluh most of the people who live in coastal areas generally work as fishermen (Widiantara et al., 2019). The story of the fishermen looking for turtle eggs is then transformed into a traditional games penyu mataluh.

Similar studies that have relevance to this study are: first, found that the values of local wisdom in the traditional game Cublak-Cublak Suweng contained five positive values presented (Kurniasari \& Rahardi, 2019). Second, stated that the traditional game of Congklak can be used as a game medium for group services to strengthen the character of children in Counseling Guidance services (Lacksana, 2017). There are values that contained in the game of congklak, namely: social sense, empathy, honesty, sportsmanship, and respect. Meanwhile, the difference is seen, namely the type of research conducted by the researcher is ethnographic qualitative. Third, resulted in a community response with a percentage of $91,8 \%$ which means very good (Widiantara et al., 2019). There is a difference that is done by the researchers, namely using the type of qualitative ethnographic research. This study aims to examine the form and value of local wisdom contained in the traditional game of the penyu mataluh in Serangan from an ethnopedagogy point of view. Data collection methods are the method of listening, recording, observing, and interviewing. Therefore, this research was conducted to answer the formulation of the problem, namely what are the forms and values of local wisdom in the traditional game of the penyu mataluh and what are the conservation strategies. In other words, this research aims to to find out the form and value of local wisdom contained in the traditional game of the penyu mataluh and the conservation strategies that can be done.

\section{MATERIALS AND METHODS}

This research uses ethnographic qualitative research (Daniel, 2016; Sugiyono, 2017). Based on this view, the data in this study were obtained through words and actions. Research data in the form of actions obtained from body movements when playing the game penyu mataluh, while the research data is in the form of words, namely song lyrics in the game penyu mataluh which shows the value of local wisdom. Data were collected by interviewing data collection methods regarding the values of local wisdom contained in the game and through observation to find out how to play and body movements that appear during the game. The data sources in this study are children who play traditional games penyu mataluh and people who understand traditional games penyu mataluh. The children who became research informants were aged between 7-12 years which were conducted on Monday, 30 November 2020. The criteria for this research were that they knew or had played traditional games penyu mataluh. The informant who comes from the community is an elder who is in an environment where traditional games are played eye turtle are still played and understand the values of local wisdom contained in traditional games penyu mataluh. This study uses descriptive data analysis techniques. Descriptive analysis includes three flow of activities, namely data reduction, data presentation, and drawing conclusions. Data reduction includes the process of selecting, simplifying, and transforming data that emerges from field notes. Presentation of data is exposure of information that allows for conclusions to be drawn. The 
data exposure is in the form of raw data from interviews, written data in verbatim form, and data that have been marked with a code while conclusions are drawn based on the presentation of the data.

\section{RESULTS AND DISCUSSION}

Based on data taken through interviews and observations, it was found that there are values of local wisdom through traditional games penyu mataluh. From an ethnopedagogy point of view. Traditional game penyu mataluh has an important function that can provide opportunities for children to assimilate reality to themselves as an implication of several concepts about the importance of playing on learning in children to create a learning environment that is conducive to learning allows children to learn while playing and play while learning effectively. Where, children can build their own knowledge through social interaction with adults while playing, especially traditional games penyu mataluh. It was first discovered in the Serangan area, South Denpasar District, Denpasar City. Based on the results of an interview with I Made Taro who is a historian as well as a maestro of traditional games information is obtained that traditional games penyu mataluh related to the geographical location of Serangan beach which is a place for turtles to lay their eggs. Most of the people who live in coastal areas generally have a profession as fishermen. Serangan Beach is a favorite place for turtles to lay their eggs and deposit their eggs in the sand so that they hatch quickly. The existence of these eggs is known by the fishermen living around the coast and becomes an attraction to be hunted and consumed. At the end of every full moon when the turtles finish laying their eggs the fishermen try to hunt for the eggs.

The story of the fishermen looking for turtle eggs is then transformed into a traditional game "penyu mataluh" which means the turtle lays eggs. Turtles are classified as protected animals because they are almost almost extinct which causes the natural ecosystem to become unbalanced. In addition, it is different from the meaning of song lyrics and games, namely ganging up to steal turtle eggs. This game activity is often interpreted as behavior that insinuates humans not to do illegal hunting of turtles or look for eggs for consumption. This game is usually played on the full moon between 18.30 and 20.00. The number of these games involves children between 5 to 12 people according to the size of the playing room. Age in between 7-12 years old. Equipment or equipment in this game only requires one place that is between 4-7 square meters. The place is then formed by making a circle with a radius of 1,5 meters and a small circle in the center. In that circle later castturtle as if laying eggs or growling eggs. Then 10-15 small stones the size of a ping pong ball must be adjusted to the number of participants.

Game penyu mataluh this is accompanied by singing bulan makalangan. The rules of the game, which is the turtle incubating the egg is in the circle. The child who acts as a fisherman will look for eggs and start singing songs bulan mekalangan as a sign the game is about to start. The fishermen who were about to steal the eggs stood outside the big circle. After singing the game started and the fishermen disturbed the turtle by dancing in front of it, behind it, beside it. They entered a large circle. Then the turtle tried to catch the fishermen who would steal the eggs. If found, the fisherman replaces position as a turtle (Taro, 2018).

In traditional games penyu mataluh contains several character values such as religious, humanist, balanced, harmonious, flexible, loving the environment, loving kindness, sincere sincerity, discipline, honest, mutual cooperation, compact, caring. There is also a philosophical concept, namely the value of environmental conservation in the penyu mataluh game Tri Hitakarana, namely the three causes or sources of welfare for mankind, which consists of a harmonious relationship between humans and God Parhyangan, human-human relationship is called Pawongan, and the relationship between humans andnature iscalled 
Palemahan. Moreover, in traditional game penyu mataluh contained local wisdom values. The values of local wisdom will be discussed in three parts according to the formulation of the research problem, namely 1) the form of local wisdom, 2) the value of local wisdom, and 3) strategies preservation that can be done.

\section{The Form of Wisdom Local in Traditional Game Penyu Mataluh}

The traditional game of the penyu mataluh contains the values of local wisdom in the form of words and deeds. The form of words in the form of song lyrics used in playing the game. Meanwhile, the form of action is in the form of game steps and body movements that appear when playing, namely (1) sitting, face down, and standing, (2) opening the palms when taking eggs, (3) moving body movements, such as feet and hands. This was also revealed by previous study that traditional games can help maximize children's gross motor development, a number of activities or games along with educational game tools are used to develop children's gross motor skills, such as sitting, face down, and standing (Sumiyati, 2018). Skills use the rising motion eye, hand and foot coordination (Farida, 2016). Movement development will develop more optimally if children can perform physical activity in various forms of play. In the form of words or language, there are song lyrics used to accompany the game penyu mataluh. The song is used during the game, also refers to the song dolanan (game). The dolanan song is a song sung while playing or a song sung in certain games using the regional language (Setyaningsih, 2019; Subagia, 2017). It was also conveyed that through play songs children will be able to play and learn to sing through physical movement, have fun, and socialize with their peers (Hardiyan et al., 2019). In addition, this dolanan can be adopted as a learning medium, especially Balinese language learning because in this game many local wisdom values are taught to children indirectly through the media playing this dolanan (Anggraeni \& Dewi, 2018). In traditional games penyu mataluh the dolanan song uses the Balinese language entitled bulan makalangan. The poetry of the bulan makalangan in terms of education teaches children to love culture and preserve the Balinese language. In addition, children are taught to improve and train their imagination and creativity through song lyrics to find out how the process of a turtle laying eggs occurs during a full moon.

The cultural values of an ethnic and educational science that are in the community can also be seen in the use of regional languages spoken by the players and through body movements that are reflected in the steps of traditional games. In traditional games penyu mataluh there are typical Serangan regional languages spoken, such as (1) bulan makalangan means the full moon that shines in full, (2) the word mataluh means laying eggs, (3) the word boko-boko which means the newly hatched tortoise, (4) malayaran means sailing, and (5) buin telun in the term of day in Balinese means three days. In addition, in the form of actions, the body movements that appear when playing are depicted. This body movement is reflected in the steps taken by the players in the game. In game penyu mataluh played by 5 to 12 children or more. One child as a turtle who served as a player and the other children played as a fisherman accompanied by a song bulan makalangan. Here are the steps game penyu mataluh.

The children who gathered as many as 10-15 people looked for a place and each prepared small stones Pimppong ball size then they make a circle with a radius of approximately $1 \mathrm{~m} 5 \mathrm{~cm}$. Then the small stones are placed in a small circle. After the preparations were completed they held a lottery with sut or um-ping-pang. If it is then the game can start. The rules of the game for those who become turtles incubate the eggs in small circles. The children who act as fishermen who will look for the eggs start singing the month of makalangan song as a sign of the start of the game. The fishermen who were about to steal the eggs stood outside the big circle. After singing the game began and the fishermen disturbed the turtle by dancing in front of it, behind it, beside it as they entered the big circle. 
The turtle tries to catch the fisherman who steals the eggs, if there is one that can be caught then he replaces it position as a turtle.

\section{The Value of Local Wisdom in The Traditional Game Penyu Mataluh}

The value of local wisdom contained in traditional games penyu mataluh in the form of certain values that are reflected in each form of local wisdom that has been described previously. Local wisdom in the form of words, namely song poems bulan makalangan first interpreted so that it can find the values contained in it. Researchers have obtained the meaning or meaning of the poem bulan makalangan the meaning or meaning of the lyrics of the song was obtained based on interviews with the community in Serangan. Song lyrics bulan makalangan the above turns out to have a deep meaning and are very close to everyday life community in Serangan. This is in line with the opinion that language is more than just a communication tool, but also a tool for compiling reality in local wisdom in the form of words or actions in the form of movements and game steps (Dharmamulya, 2008; Heriawan et al., 2018). Traditional games have an important place in people's lives and are useful for instilling attitudes and skills that are channeled in free time as a place of entertainment so that they have local wisdom values that can be seen as positive attitudes (Kartiningsih \& Budiaman, 2020; Munawaroh, 2017). Local wisdom has an important role and function for the conservation and preservation of natural resources, the development of human resources, and the development of culture and science (Prayogi \& Danial, 2016; Ratih, 2019). Based on the expert opinion, it can be concluded that the local wisdom contained in traditional games has positive attitudes that are manifested through words and actions. This attitude is closely related to positive values. The values in local wisdom in the form of words and deeds can be described as follows.

\section{Togetherness}

The game of penyu mataluh contains the value of togetherness because the game can not be done alone. To be able to play penyu mataluh a minimum of 5 children is required as a player. The more players, the more fun the game will be. In addition, the rules contained in the game must be obeyed by all players. If someone doesn't sing or doesn't move, then the pace of the game will not be good. The value of togetherness is also seen, the more players, the livelier the game will be. Moreover, from the point of view of education in traditional games penyu mataluh it is also seen that the value of togetherness in its implementation lies in three things, including: (a) Togetherness has the value of humility (Anggita, 2019; Fatria, 2016). Humility will enable us to cooperate, not to seek self-interest, or vain praise. Humble people do not seek human praise. People who are humble will find it easier to think of other people as more important / important than themselves. (b) Togetherness has service value. Service is not self-oriented, but pays attention to the interests of others. This means that to achieve togetherness we need to serve others, anyone, especially those who need our helping hand. (c) Togetherness has value in mind. In togetherness there are many characters, each individual has a different character, a different perspective, and a different way of thinking which results in different life principles

\section{Educational value}

The educational value of this game can be seen in the direct experience felt by the player penyu mataluh and get the main place in acquiring knowledge. Meanwhile in the world education, successful learning is learning by experiencing yourself, exploring yourself, looking for yourself and finally getting what you are looking for (Ananda, 2017; Prastowo, 2018). Learning is experience, exploration and discovery and all that in traditional games penyu mataluh. This game teaches someone to know the steps to implement the game, 
namely in the accuracy of children playing as turtles and fishermen. After the song is finished, the child who becomes a turtle or who does not become a turtle must try to catch the fishermen and try to protect their eggs so they are not hunted. Thus, children who play as turtles must be careful and pay close attention to actions through dances performed by fishermen. This game trains children to be critical in making strategies so that it is not easy to defeated by the turtle and observed the facial expressions of each child fisherman. Play is used to find out the child's strengths and weaknesses. Children practice to think critically which can be one of the strengths in children. Based on that, the game penyu mataluh able to construct cognitive or intelligence aspects through optimizing the performance of the left and right brain. In addition, this educational value can train children's language skills. This was also conveyed that one aspect of development that also develops during play is the aspect of language development (Aqobah et al., 2020). Language is a bridge of human communication with the surrounding environment and helps a person to express various ideas, meanings, feelings and experiences. Language development includes the development of speaking, writing, reading, and listening. Traditional games can be a medium for communication, especially if the form of the game is in groups.

\section{The value of social education}

The value of social education is reflected in traditional games penyu mataluh because in this game it takes several people involved consisting of 5-12 players, indirectly in this game teaches children to relate to other humans as social beings and establish a good communication to get a goal to win in the game eye turtle. In addition, the game does not discriminate against nation, religion or social status. In the event of playing, all have the same interests, all must comply with the rules of the game, all must submit to the referee who leads, willing to admit the opponent's superiority and do not need to brag when experiencing victory. In lessons, joint exercises, Well-organized matches can always be used as a means to foster a social approach between those who do it (Prasojo, 2020).

\section{Creativity}

In this stage the children in carrying out the game penyu mataluh able to give birth to different innovations in the form of movement formation, revision of game rules, and revision of their work. It can be seen clearly when the game before it starts the children explain the rules of the game that are will be mutually agreed even in the middle of the game a lot of movements that appear in the game penyu mataluh this can be seen when a fisherman is hunting for turtle eggs and the turtle will make several movements to catch the fisherman. In addition, in the world of education, the value of creativity is needed to hone students' abilities in observing the environment and processes learning so that later could develop students' intellectuals (Holis, 2016; Wahyuni et al., 2016).

\section{Caring for the environment}

Indirectly, this game reveals that the meaning behind the story of the fishermen looking for turtle eggs is then transformed into traditional games penyu mataluh which means the turtle lays eggs. Turtle belongs to animal that protected because it almost experienced extinction which caused the natural ecosystem not to be in balance. This game activity is often interpreted as behavior that insinuates humans so that they do not carry out illegal hunting of turtles or seekeggs for consumption so that the turtles are no longer threatened with extinction. There is an educational goal of environmental care character values which are reflected in traditional games penyu mataluh, namely: (a) encouraging commendable habits and behavior of students and in line with proper environmental management; (b) improve the ability to avoid properties that can damage the environment; (c) fostering the 
sensitivity of students to environmental conditions so that they can avoid properties that can damage the environment; (d) cultivate a caring and responsible spirit towards environmental sustainability. The end goal is that students and children can become environmental ambassadors for schools, homes, and the surrounding environment and make these attitudes or characters into their habits in life wherever they are. The character of caring for the environment is not only theoretical but requires a real action that brings good changes to everyone's life. This was also revealed in the research that environmental care character aims to encourage the habit of managing the environment, avoiding environmental damage, fostering sensitivity to the environment, plant a caring soul and responsibility to the environment, and students can be an example of environmental saviors in life wherever they are (Efendi et al., 2020; Purwanti, 2017).

\section{Traditional and cultural values}

Traditional values in the game penyu mataluh is a type of traditional game that is only played at the time of the full moon, even in areas that are only allowed to play only in Serangan. This is a tradition and culture that is owned by the village as a resident on the coast. In addition, it can be seen in the lyrics of the song's lyrics bulan makalangan. The language used reflects the characteristics of Bali with the words that are poured. There is a meaning in every verse of the song that is sung, such as "bulan makalangan penyu ne mataluh", which means that the full moon has come, it's time for the turtles to go to the coast to lay their eggs, implicitly teaching humans that we should be able to keep the environment clean as a place for turtles to lay eggs. In addition, every time we play the game, we don't forget to sing the lyrics of the song bulan makalangan. In this case, we can maintain the traditional and cultural values contained in this game. From the aspect of education, these traditional and cultural values can be used as guidelines for children to behave and develop intellectually in learning knowing the various traditions that must be preserved and knowing that the value of a culture is a rule contained in public relations in the process of balancing, harmonizing and balance between goals and reality (Kartiningsih \& Budiaman, 2020; Lacksana, 2017). So that children will gain knowledge that the meaning of cultural values is a series of systems in society that influence and be used as an alternative to get rights and obligations that are carried out.

\section{Honesty}

The value of honesty contained in the game penyu mataluh is when the turtle catches the fishermen, the fisherman replaces his position as a turtle. The value of honesty is also seen in every child who is always honest when he loses and is caught, he sincerely surrenders himself. In their defeat in this game without any element of compulsion to get out of the game or getting angry with a partner who succeeded catch him. The value of honesty has also been found in research which states that honesty is the main basis for a child to be trusted in his environment (Futihat, 2020; Khotimah et al., 2020).

\section{The value of mutual cooperation}

In terms of education, traditional games penyu mataluh can increase the value of mutual cooperation can be seen when the fishermen who together distract the turtles, so that later fishermen can steal the eggs. Therefore, the attitude of mutual cooperation was shown by all the players to work hard together to get turtle eggs as their prey. Seen in the movement that is pulled by the fishermen together to perform dance movements from the side, front, and back to the back with the aim of scaring the turtles and distracting them. his attention. This is in line with research which states that the movements carried out by fishermen are activities 
carried out together and with the aim of facilitating a job to make it easy and light (Holis, 2016; Widiantara et al., 2019).

\section{Religious values}

The value of religious character seen from the initial activities before playing the game penyu metaluh namely praying together. This teaches the younger generation that in order to start a job as God's creatures, we need to pray to give thanks and beg smoothness. In addition, religious characters can be seen by not distinguishing between friends in the game, even though they come from different religions, economic backgrounds, and different education. However, they can still play the game together without any sense of discrimination. This was also expressed that the value of religious character is very much needed by students in dealing with changing times and moral degradation, in this case students are expected to be able to have and behave with good and bad measures based on religious provisions and provisions (Ahsanulkhaq, 2019; Rifai, 2021). This has been reflected in a traditional game penyu mataluh.

\section{Independent}

In this case seen in the game penyu mataluh, the value of independent character is seen in the turtle actor who is strong, hard work, and never give up to protect the eggs. It looks like the players are very enthusiastic and work hard to block and protect the turtle eggs from the hunters. In the world of education, the success of a child in undergoing the educational process is not only determined by Intelligence Quotient, However, it is influenced by the value of independent character which can provide very important lessons to children so that in the future they are physically and mentally ready to carry out interactions and activities. various activities in the community. Therefore, penyu mataluh can train students' independent attitude from an early age. It was revealed in a research that the success of a child in undergoing the educational process is not determined by IQ (Intelligence Quotient) (Husna, 2017; Labudasari \& Rochmah, 2019). However, it is influenced by many factors, one of which is the independent character of students. Independent students will be able to develop and organize themselves so that the desired goals can be achieved.

\section{Discipline Value}

In the traditional game, this discipline is reflected when there are children who play the game first to make an agreement to determine the rules in the game. For the child who is the winner who manages to steal turtle eggs, the losing child will be willing to accept punishment and are prohibited from cheating in breaking the agreement that has been agreed upon in the rules that have been made previously. In the world of education, the rules that are used to be accepted by children will have a positive impact on children's development in the environment community and school. The first function of school regulations is to regulate student behavior while in the school environment. The next function of school regulations is as a means of education. The existence of school rules will introduce students to good behavior that needs to be accustomed. That way, students can more easily blend in with the wider life, namely society. This is important to create a conducive, safe, and comfortable environment for learning. Rules are also made so that students can respect the rules and learn to control themselves. This was also conveyed in a research which stated that the functions of school regulations include creating discipline, practicing responsibility, streamlining teaching and learning activities, strengthening the role of students, practicing honesty, independence, practice social skills, eliminate social jealousy, enhance a sense of community, and maintain comfort (Hidayat et al., 2017; Maskuri, 2018; Sobri et al., 2019). Therefore, the traditional mataluh turtle game can train children's discipline values. 


\section{Nationalism}

The value of nationalism is also found in traditional games eye turtle which shows an attitude of love for the homeland and preserving local wisdom. This means that although the development of technology in Industry 4.0 is very rapid, as a young generation it is necessary to maintain the preservation of local culture so that it does not become extinct and fade away by the era of globalization. The value of nationalism can be seen directly in a traditional game activity so as to preserve the local wisdom itself. It was also revealed that in traditional games children can learn local culture in hopes of improving the values of nationalism (Aswasulasikin et al., 2020; Lestari et al., 2018). The values of nationalism are very important for students to maintain the cultural values of the nation and the country that are embedded in the character of the nation's children from an early age. Instilling a love for the nation's culture through traditional games in the archipelago, one of the traditional games is that turtles can foster the value of nationalism in children.

\section{Strategy Preservation that Could Done}

Based on exposure to the form and meaning of local wisdom in traditional games penyu mataluh it can be seen that the true traditional game has various values which are local wisdom. However, it is undeniable that traditional games are no longer played by children due to several factors, including the limited number of child births, reduced playing area, and technological advances. If this continues, it is feared that traditional games will become extinct. The extinction of traditional games can be prevented through conservation measures. Preservation of traditional games is very important so that future generations will still know the types of games in their ancestors' days. In addition, the preservation strategy is carried out on the game Traditional symbols can symbolize truth (satyam), holiness (sivam) and beauty (sundaram) (Subagia, 2017). From an educational perspective, traditional games are also taught how to develop skills in dancing, singing, acting, and playing music. Based on the research activities that have been carried out, the game penyu mataluh also has local wisdom values. These traditional games contain teachings about noble behavior that are packaged in the form of games and song lyrics that are used as a means of passing on Balinese cultural values to children. Therefore, efforts are needed to preserve traditional games. Preservation strategy is an activity to preserve library materials that includes all managerial considerations, especially on traditional game penyu mataluh.

Every year Denpasar City holds a performance or performance with the theme of art and tradition. Children's play is also a routine event that is carried out in the PKB (Bali Arts Festival) activities which are held every June to July. This indicates positively that the existence of dolanan children need to be cared for so as not to become extinct. In addition, there are several efforts that can be made to preserve traditional games. However, the rapid development of globalization and communication technology is a challenge in preserving traditional games that feel outdated when compared to other modern types of games, because of the rapid flow of globalization, it is undeniable that traditional games will continue to be eroded and can disappear. To address that local wisdom must be in line with the development of the times, for example making games applications that can be downloaded on mobile phones. Mobile phones are electronic telecommunications equipment that has the same basic capabilities as conventional telephones that have channels and various music applications, games, art, photos, social and more (Lacksana, 2017). That matterin line with the opinion that the use of game applications found on mobile phones can help preserve traditional games by using new forms of packaging (Kurniasari \& Rahardi, 2019). Based on the above opinion, to preserve traditional games, you can use applications from mobile phones by realizing games that are similar to games penyu mataluh. 
In preserving local wisdom, it is possible to bring back past traditions to create an interpretation of a local traditional value with a process of change ( transforms) which is adapted to the point of view, technology and today's needs, even though its form is different from its original form so that the tradition will continue, as revealed in the results of the research which provides recommendations to preserve the values of local wisdom in Indonesia (Kurniasari \& Rahardi, 2019). Traditional game by involving parents, the community, cultural studios, schools, and the government to teach the values of local wisdom to the younger generation and facilitate the preservation of the values of local wisdom. This is in line with research which states that schools as institutions for educating children are very appropriate when used as land to preserve traditional games because there are large numbers of children available as players. limited number of children (Prastowo, 2018). On the other hand, it contains positive values in traditional games while at the same time teaching good character values. Thus, it is hoped that children can grow up to be intelligent and good personalities. The game in terms of function is essentially a means of entertainment, so feelings of joy and pleasure can be obtained by children by playing games. Traditional games can be taught at the kindergarten and elementary school levels, in several interviews, the teachers suggested that traditional games be taught in schools so that students still know traditional games even though they are living in this digital era. On the other hand, there are ways to preserve traditional games that can be done by educational practitioners and cultural practitioners.

It is hoped that more research will emerge in the field of local wisdom values in traditional games in the future. With the increasing number of research in this field, the more people who know information about the values of local wisdom in traditional games. It is undeniable that not everyone knows the values of local wisdom in traditional games because not everyone also has the opportunity to know these traditional games. With the existence of research articles in the field of local wisdom values in traditional games, the community reminded and made aware of one of the cultural heritages of our ancestors, namely the traditional game which turned out to be contains local wisdom values. As citizens, we are obliged to protect and preserve this ancestral heritage. This research has been maximally attempted and of course there are limitations in this research, including: limited written sources in the game penyu mataluh and in the process of data collection, the researcher did not obtain literature that specifically describes traditional games in this area. The implication of this research is to contribute to science in order to add references to the value of local wisdom in traditional games. In addition, we invite researchers to examine variables that have not been studied in the study to be used as guidelines for further refinement of this study

\section{CONCLUSION}

Traditional game of turtle penyu mataluh is one of the cultural heritages of the Indonesian nation that has the characteristics and values of local wisdom that can foster postif values in the development of children. The traditional game of penyu mataluh was created not originally in the maker, but behind the game is stored moral content that is useful to grow the character for the child. In addition, traditional games can be used as a means for children to gain experience. Helping children develop various aspects of holistic and integrated development and the development of various positive characters such as improving social behavior and social interaction of children to the environment. Building cooperation with peers, being able to solve problems as part of cognitive development, as well as helping rough motor development in children. Therefore, there needs to be socialization and preservation of traditional games in a sustainable manner. 


\section{REFERENCES}

Ahsanulkhaq, M. (2019). Membentuk Karakter Religius Peserta Didik Melalui Metode Pembiasaan. Jurnal Prakarsa Paedagogia, 2(1), 21-33. https://doi.org/10.24176/jpp.v2i1.4312.

Ananda, R. (2017). Implementasi Nilai-nilai Moral dan Agama pada Anak Usia Dini. Jurnal Obsesi: Jurnal Pendidikan Anak Usia Dini, $1(1), \quad 19$. https://doi.org/10.31004/obsesi.v1i1.28.

Anggita, G. M. (2019). Eksistensi Permainan Tradisional sebagai Warisan Budaya Bangsa. JOSSAE: Journal of Sport Science and Education, 3(2), 55. https://doi.org/10.26740/jossae.v3n2.p55-59.

Anggraeni, N. P. L., \& Dewi, K. A. P. (2018). Dolanan Sebagai Media Pendidikan Karakter Pada. ADI WIDYA: Jurnal Pendidikan Dasar, 3(April), 1-6. http://www.ejournal.ihdn.ac.id/index.php/AW/article/view/900.

Aqobah, Q. J., Ali, M., Decheline, G., \& Raharja, A. T. (2020). Penanaman Perilaku Kerjasama Anak Usia Dini Melalui Permainan Tradisonal. Jurnal Eksistensi Pendidikan Luar Sekolah (E-Plus), 5(2), 134-142. https://doi.org/10.30870/eplus.v5i2.9253.

Aswasulasikin, A., Pujiani, S., \& Hadi, Y. A. (2020). Penanaman Nilai Nasionalis Melalui Pembelajaran Budaya Lokal Sasak Di Sekolah Dasar. Jurnal Didika: Wahana Ilmiah Pendidikan Dasar, 6(1), 63-76. https://doi.org/10.29408/didika.v6i1.2027.

Daniel, E. (2016). The Usefulness of Qualitative and Quantitative Approaches and Methods in Researching Problem-Solving Ability in Science Education Curriculum. Journal of Education and Practice, 7(15), 91-100. https://doi.org/2222-288X.

Dharmamulya, S. (2008). Permainan Tradisional Jawa. Kepel Press.

Efendi, Nofriza, Barkara, R. S., \& Fitria, Y. (2020). Implementasi Karakter Peduli Lingkungan di Sekolah Dasar Lolong Belanti Padang. Jurnal Komunikasi Pendidikan, 4(2), 1-10. http://journal.univetbantara.ac.id/index.php/komdik/article/view/460/pdf.

Farida, A. (2016). Urgensi Perkembangan Motorik Kasar pada Perkembangan Anak Usia Dini. Jurnal Raudhah, 4(2), 1-10. https://doi.org/10.30829/raudhah.v4i2.52.

Fatria, F. (2016). Analisis Nilai-nilai Edukatif dalam Novel Sepatu Dahlan Karya Khrisna Pabichara. Jurnal Penelitian Pendidikan Bahasa Dan Sastra, 1(1), 1-10. https://jurnal-lp2m.umnaw.ac.id/index.php/JP2BS/article/view/17.

Futihat. (2020). Penerapan Pendidikan Karakter Format Kelompok Untuk Meningkatkan Nilai Kejujuran Siswa. Jurnal Pendidikan Berkarakter, 3(2), 28-31. https://doi.org/10.31764/pendekar.v3i2.2818.

Hardiyan, R. C., Aesijah, S., \& Suharto. (2019). Pembelajaran Lagu Dolanan Untuk menanamkan Nilai Karakter Pada Siswa SD Negeri Sekaran 01. Jurnal Seni Musik, 8(2), 105-115. https://doi.org/10.15294/jsm.v8i2.35048.

Heriawan, A., Soetrisnaadisendjaja, D., \& Hidayati, S. (2018). Kajian Etnopaedagogi : Seba Dalam Masyarakat Baduy. Jurnal Hermeneutika, 4(2), 47-56. https://jurnal.untirta.ac.id/index.php/Hermeneutika/article/view/4831/3473.

Hidayat, A., Andra, I., \& Kartadinata, dan S. (2017). Students' Peaceful Mentality and Pesantren-based School Rules. Jurnal Kependidikan: Penelitian Inovasi Pembelajaran, 1(1), 111-124. https://doi.org/10.21831/jk.v1i1.10440.

Holis, A. (2016). Belajar Melalui Bermain untuk Pengembangan Kreativitas dan Kognitif Anak Usia Dini. Jurnal Pendidikan UNIGA, 10(1), 23-37. http://journal.uniga.ac.id/index.php/JP/article/view/84.

Husna, L. (2017). Pendidikan Karakter Mandiri pada Siswa Kelas IV SD Unggulan Aisyiyah Bantul. Jurnal Pendidikan Guru Sekolah Dasar, 6(10), 964-974.

Kartiningsih, \& Budiaman. (2020). Strategi Komunitas Traditional Games Returns (TGR) 
dalam Pelestarian Permainan Tradisional Pada Anak Usia 7-12 Tahun (Studi Kasus di RW 03, Kelurahan Cakung Timur, Kecamatan Cakung, Kota Jakarta Timur). Jurnal Edukasi Ips, 4(1), 50-60. https://doi.org/10.21009/EIPS.004.1.06.

Khotimah, R. P., Putro, D. S., Utomo, G. W., Hidayah, A. F., Astrianti, N. E., Sari, Y. R., Alfanani, T. R., Muthmainnah, H. T., Mazliza, \& Zakiah. (2020). Penanaman Karakter Kejujuran Melalui Kantin AntiKorupsi pada Siswa SD/MI Ngargorejo, Ngemplak, Boyolali. Buletin KKN Pendidikan, 2 (1), 24-27. https://doi.org/10.23917/bkkndik.v2i1.11167.

Kurniasari, Y. R., \& Rahardi, R. K. (2019). Nilai-Nilai Kearifan Lokal Dalam Permainan Tradisional Cublak-cublak Suweng Di Yogyakarta: Kajian Ekolinguistik. Jurnal Pendidikan Bahasa Dan Sastra Indonesia, 8(2), 134-142. https://doi.org/10.15294/jpbsi.v8i2.30877.

Labudasari, E., \& Rochmah, E. (2019). Pengaruh gerakan literasi sekolah terhadap karakter mandiri siswa di SDN Kanggraksan Cirebon. Premiere Educandum: Jurnal $\begin{array}{llll}\text { Pendidikan Dasar Dan } & \text { Pembelajaran, }\end{array}$ https://doi.org/10.25273/pe.v9i1.4254.

Lacksana, I. (2017). Kearifan Lokal Permainan Congklak Sebagai Penguatan Karakter Peserta Didik Melalui Layanan Bimbingan Konseling Disekolah. Satya Widya, 33(2), 109-116. https://doi.org/10.24246/j.sw.2017.v33.i2.p109-116.

Lestari, S. U., Saraswati, U., \& Muntholib, A. (2018). Penanaman Nilai-nilai Nasionalisme dalam Pembelajaran Sejarah Lokal Perjuangan Rakyat Sukorejo Kelas XI di SMA Negeri 1 Sukorejo. Indonesian Journal of History Education, 6(2), 205-215. https://journal.unnes.ac.id/sju/index.php/ijhe/article/view/27652.

Maskuri. (2018). Pendidikan Karakter Disiplin Di Lingkungan Sekolah. Jurnal Tawadhu, 2(1), 340-363. https://ejournal.iaiig.ac.id/index.php/TWD/article/view/3.

Munawaroh, H. (2017). Pengembangan Model Pembelajaran dengan Permainan Tradisional Engklek Sebagai Sarana Stimulasi Perkembangan Anak Usia Dini. Jurnal Obsesi : Jurnal Pendidikan Anak Usia Dini, 1(2), 86. https://doi.org/10.31004/obsesi.v1i2.19.

Prasojo, Z. H. (2020). Nilai Kebersamaan Pada Tradisi Belalle' Diaspora Melayu Sambas. DIALEKTIKA: Jurnal Pemikiran Dan Penelitian Pendidikan Dasar, 13(01), 53-63. https://jurnal.iainambon.ac.id/index.php/DT/article/view/1395/pdf.

Prastowo, A. (2018). Permainan Tradisional Jawa Sebagai Strategi Pembelajaran Berbasis Kearifan Lokal Untuk Menumbuhkan Keterampilan Global Di Mi/Sd. JMIE (Journal of Madrasah Ibtidaiyah Education), 2(1), 1. https://doi.org/10.32934/jmie.v2i1.55.

Prayogi, R., \& Danial, E. (2016). Pergeseran Nilai-Nilai Budaya Pada Suku Bonai Sebagai Civic Culture Di Kecamatan Bonai Darussalam Kabupaten Rokan Hulu Provinsi Riau. Humanika, 23(1). https://doi.org/10.14710/humanika.v23i1.11764.

Purwanti, D. (2017). Pendidikan Karakter Peduli Lingkungan Dan Implementasinya. DWIJA CENDEKIA: Jurnal Riset Pedagogik, 1(2), 14-20. https://doi.org/10.20961/jdc.v1i2.17622.

Ratih, D. (2019). Nilai-Nilai Kearifan Lokal dalam Tradisi Misalin di Kecamatan Cimaragas Kabupaten Ciamis. ISTORIA: Jurnal Pendidikan Dan Sejarah, 15 (1), 45-57. https://doi.org/10.21831/istoria.v15i1.24184.

Rifai. (2021). Hubungan Tingkat Religiusitas terhadap Kecemasan Moral dan Alternatif Pembinaan Moral pada Kenakalan Siswa. Jurnal Teologi Gracia Deo, 3(2), 76-87. https://doi.org/10.46929/graciadeo.v3i2.63.

Setyaningsih. (2019). Nilai-Nilai Pendidikan Karakter Dalam Lirik Tembang Dolanan Jawa Values Character Education In Song Dolanan Java. Widya Aksara, 24(2).

Sobri, M., Nursaptini, Widodo, A., \& Sutisna, D. (2019). Pembentukan karakter disiplin siswa melalui kultur sekolah. Harmoni Sosial: Jurnal Pendidikan IPS, 6(1), 61-71. 
https://doi.org/10.21831/hsjpi.v6i1.26912.

Subagia, N. (2017). Aspect of Art And Meaning of Staging The Traditional Dolanan Game In Sanggar Kebo Iwa Badung. Mudra Jurnal Seni Budaya, 32(3), 360-365. https://doi.org/10.31091/mudra.v32i3.147.

Sugiyono. (2017). Metode Penelitian Kualitatif. Bandung: Alfabeta.

Sumiyati, S. (2018). Metode Pengembangan Motorik Kasar Anak Usia Dini. AWLADY: Jurnal Pendidikan Anak, 4(1), 78. https://doi.org/10.24235/awlady.v4i1.2509.

Susanti, M. M. (2016). Nilai-Nilai Pendidikan pada Cerita Anak dalam Koran Padang Ekspres. Jurnal STKIP PGRI Sumbar, 2(1), 51-54. http://repo.stkip-pgrisumbar.ac.id/id/eprint/5191/.

Taro, M. (2018). Dari Ngejuk Capung Sampai Ngejuk Lindung. Amanda Press.

Wahyuni, I., Khutobah, K., \& Yuliati, N. (2016). Peningkatan Kreativitas dalam Membuat Bentuk pada Anak Kelompok B2 melalui Bermain Play Dough di TK Plus Al-Hujjah Keranjingan Sumbersari Jember Tahun Pelajaran 2015/2016. Jurnal Edukasi, 3(2), 1. https://doi.org/10.19184/jukasi.v3i2.3520.

Widiantara, D. M., Pradnyana, I. M. A., \& Sindu, I. G. P. (2019). Film dokumenter Permainan Tradisional "Penyu Mataluh". Kumpulan Artikel Mahasiswa Pendidikan $\begin{array}{llll}\text { Teknik Informatika } & \text { (KARMAPATI), }\end{array}$ https://doi.org/10.23887/karmapati.v8i2.18394. 